\title{
Criminal Responsibility for Violation of Sanitary and Epidemiological Legislation in the Aspect of the Introduced Changes on the Background of New Coronavirus Infection (2019-nCoV)
}

\author{
Soshnikova I.V. ${ }^{1}$ Rukoleev V.A.,** \\ ${ }^{1}$ Ural State University of Economics, Ekaterinburg 620144, Russia \\ ${ }^{2}$ Ural State Law University, Ekaterinburg 620144, Russia \\ *Corresponding author.Email: v.a.rukoleev@bk.ru
}

\begin{abstract}
This study criticizes the amendments made against the background of a new coronavirus infection (2019-nCoV) to part 1 of Article 236 of the Criminal Code of the Russian Federation, which cause the initiation of criminal prosecution for violation of sanitary and epidemiological rules in the process of industrial or household activities (including for non-compliance with non-normative acts), the consequences why they can cause a threat of mass illness or poisoning of people. The authors believe that the alternative corpus delicti, added by the legislator, competes with the identical corpus delicti of an administrative offense provided for in Article 6.3 of the Administrative Code of the Russian Federation. In practice, such legislative imperfection predetermines the emergence of controversial issues when qualifying according to the administrative-legal or criminal-legal norm. Arguing their position, the authors formulated and analyzed model situations of violations by individuals or business entities of sanitary and epidemiological legislation that are ubiquitous in everyday life.
\end{abstract}

Keywords: crime, responsibility, administrative offense, threat, disease, sanitary and epidemiological rules, coronavirus infection

\section{INTRODUCTION}

In conditions of an unfavorable epidemiological situation caused by the spread of coronavirus infection (2019-nCoV) in the territory of the Russian Federation, there is a need to develop preventive measures aimed at reducing infectious activity among the population. An equally important task was to legislatively adapt the preventive mechanism to the modern realities of the preventive mechanism in order to strictly comply with existing and enacted sanitary regulations, ensure information security of the population, as well as maintain general law and order during a pandemic. As a result, a number of changes have been made to the administrative and criminal legislation. A special part of the Code of Administrative Offenses of the Russian Federation (hereinafter referred to as the RF CAO) [1] and the Criminal Code of the Russian Federation (hereinafter referred to as the RF CC) [2] has been supplemented with new compositions of illegal acts recognized as such, including for creating a threat to life, health or safety a person and a citizen, specified in the disposition of the corresponding norm. After several months, against the background of a stabilized situation, the authors are inclined to assert that all the measures taken meet the challenges of the time. But, the adequacy of some of them, subjectively speaking, is questioned.

Having analyzed the array of short stories in the legislation, the achieved content of Part 1 of Article 236 of the RF CC causes bewilderment. From the point of view of the sectoral affiliation of types of legal liability, built in the Russian legal system, it was allowed to substitute an administrative offense with a criminal offense. Result: part 1 and 2 of article 6.3 of the RF CAO competes with part 1 of article 236 of the RF CC. Moreover, the competition in this case is absolute, without the presence of distinctive features in the aforementioned identical compositions. In practice, such legislative imperfection predetermines the emergence of controversial issues when qualifying according to the administrative-legal or criminal-legal norm. An earlier study of law enforcement practice, which is relatively close in meaning to the problem under discussion, showed that officials acting on behalf of and in pursuance of the law are fundamentally disposed exclusively for the second option [3, p. 661 - 669].

\section{MATERIALS AND METHODS}

The research is based on the theoretical and empirical methodology of scientific knowledge, which includes both general scientific and special legal methods. In addition, in the process of writing the work, a systematic-and-structural approach to the consideration of the studied problem was implemented. The peculiarity of the achieved content of the article is the combination of complex and comparative legal research.

The set of scientific tools selected by the authors helps the reader not only to immerse himself in the problem of the 
consistency of the changes introduced against the background of a new coronavirus infection (2019-nCoV) to Article 236 of the RF CC, but also to form his personal attitude to the preventive mechanism adapted in the Russian Federation to modern realities in general.

The information base of the study includes: works of domestic scientists devoted to the problems of determining the qualifying signs of a threat in the meaning of the method of committing a crime, scientific articles published in periodicals, Internet resources, as well as regulatory legal acts and judicial practice.

\section{RESULTS AND DISCUSSION}

The authors propose to divide this section into practical and theoretical problems of the achieved content of Article 236 of the Criminal Code of the Russian Federation.

\subsection{Practical issues of the consistency of changes introduced against the background of a new coronavirus infection to Article 236 of the Criminal Code of the Russian Federation}

The criticized amendment introduced by the Federal Law "On Amendments to the Criminal Code of the Russian Federation and Articles 31 and 151 of the Criminal Procedure Code of the Russian Federation" [4] stipulates the initiation of criminal prosecution for violation of sanitary and epidemiological rules in the process of industrial or household activities (including for noncompliance with non-normative (individual) acts), the consequences of which may cause a threat of mass illness or poisoning of people. At the same time, not every violation of legislation in this area should be considered a danger to the life and health of an unlimited number of people. The determining factor, in addition to the object in the quantitative expression of "mass", is the alleged subject of the crime. The threat to the aforementioned protected public relations mainly comes from officials of business entities and persons - carriers of pathogens that pose a danger to others [5].

If everything is more or less clear with officials of economic entities due to the fact that in order to be recognized as an appropriate subject of a crime, it is enough to study the employment contract, job description, local acts of the organization on the assignment of duties, then there is ambiguity with the last category. Firstly, the following question arises: "Is a person who does not know for objective reasons that he/she suffers from an infectious disease (for example, an asymptomatic course of a viral infection in the body) and at the same time endangers the transmission of the causative agents of this disease to others, subject to the criminal liability?". Certainly is, since the subjective side of the corpus delicti provided for in Part 1 of Article 236 of the RF CC is characterized by a careless form of guilt in the form of a frivolous or negligent attitude towards the potential to harm the life and health of an indefinite circle of persons. The difficulty lies in the difference between the violation of sanitary and epidemiological rules without creating an already known threat and with the creation of one. The Supreme Court of the Russian Federation tried to give an answer. However, as they say, the authors failed to catch the train of thought. After considering the reviews on certain issues of judicial practice related to the application of legislation and measures to counter the spread of a new coronavirus infection in the territory of the Russian Federation, the impression was formed not only of aloofness from developing events, but also of the inability of the higher court to provide appropriate explanations in order to ensure the uniform application of legislation lower courts. In fact, the last two thematic reviews approved by the Presidium of the Supreme Court of the Russian Federation openly provide for an excessive margin of discretion in assessing the circumstances that affect the qualification of the act. To confirm the above, we will specify the most relevant examples from practice.

The first example. An individual who does not suffer from an infectious disease violated the requirement of a senior official of a constituent entity of the Russian Federation to use personal respiratory protection equipment (sanitary and hygienic masks, respirators) in public places and public transport during a period of high alert on the territory of a constituent entity of the Russian Federation. The second example. An individual does not self-isolate at home under the same circumstances. Acts are subject to qualification under Part 1 of Article 20.6.1 of the RF CAO, under Part 2 of Article 6.3 of the RF CAO, or maybe under Part 1 of Article 236 of the RF CC? According to the provisions of the first thematic review [6], Part 2 of Article 6.3 of the RF $\mathrm{CAO}$ is a special rule in relation to the related composition of an administrative offense. The general criterion for qualification is the violation of the rules of conduct when the regime of high alert or an emergency situation is introduced, approved by the Government of the Russian Federation [7] and additional rules adopted at the level of the constituent entity of the Russian Federation, the boundary is a violated legal norm. Further concretization in the judicial act is reduced to giving examples that have no informational value. A similar manner may be applied to the second thematic review [8], in which, in relation to the question posed, only an explanation is given to the concepts of "mass disease or poisoning of people" and "creating a threat of consequences" already studied in criminal law science.

Thus, in the absence of a legal answer, the author's position is based on the fact that it is necessary to qualify violations of time constraints set forth in acts with normative properties, taking into account the consequences that have occurred, according to Article 20.6.1 of the RF CAO. Actions (inaction) that run counter to the non-normative instructions of the body (official) exercising federal state sanitary and epidemiological supervision, being individually warned about the occurrence of responsibility, taking into account the consequences that have occurred, should be qualified under Article 6.3 of the RF CAO. The differentiation was based on the degree of public danger in 
relation to the variability of the upper and lower limits of the imposed sanction for committing these administrative offenses against citizens, officials and legal entities provided for by the current legislation. With regard to criminal liability, it is appropriate to cite the conclusion of the Constitutional Court of the Russian Federation, formulated in the Definition of 2003: "... by virtue of its legal nature, the extreme means by which the state responds to the facts of offensive behavior, extends its action only to those spheres of public relations, the regulation of which with the help of legal norms of a different branch, including norms establishing administrative responsibility, turns out to be insufficient" [9]. Therefore, the cases actively developing in law enforcement practice, covered by the media, qualifications of actions of individuals suffering from diseases that pose a danger to others, or with suspicion of such diseases, according to the criminal law for unauthorized leaving places of forced hospitalization (isolation), need thorough assessment in the scientific environment.

\subsection{Theoretical issues of the consistency of changes introduced against the background of a new coronavirus infection to Article 236 of the Criminal Code of the Russian Federation}

The problematic aspect considered herein, from the perspective of an unfavorable epidemiological situation caused by the spread of coronavirus infection in the territory of the Russian Federation, needs to be supplemented with a brief theoretical justification affecting a full understanding of the collision made by the legislator between parts 1 and 2 of article 6.3 of the Administrative Code of the Russian Federation and part 1 of article 236 of the RF CC.

Traditionally, in criminal law science, the creation of a threat of harm to public relations is understood as a criminalization condition that allows the qualification of an unlawful action (inaction) as criminal only for creating a real danger of the onset of the consequences specified in the disposition of the article of the Special Part of the RF CC. Most of the legal scholars, including O.I. Korostylev [10, p. 37] and Ye.N. Makarova [11, p. 100-102], completely justifiably personify a threat-act with a psychological impact on an individual, a group of persons, society due to the emerging subjective unpredictability in the implementation of antisocial intentions. A different interpretation of the threat is given by the Plenum of the Supreme Court of the Russian Federation. In the clarifying acts on judicial practice in cases of crimes of a terrorist [12] and environmental orientation [13], the content of the concept of "creating a threat of harm to public relations" is associated with the occurrence of a situation that could entail harmful consequences stipulated in the law, if they were not prevented by the measures taken or other circumstances beyond the control of the will of the person who broke the law. Based on the foregoing, the objective side of the corpus delicti when creating a threat of harm includes several elements: an act and a legal assessment of the possibility of consequences. The last element is restrictive, since in its absence the crime is not recognized as a crime. The subjective side of such acts can be characterized by a deliberate or reckless form of guilt. In terms of its external manifestation, the alternative composition introduced in part 1 of Article 236 of the RF $\mathrm{CC}$, which provides for the onset of responsibility for creating a threat of mass illness or poisoning of people, is in many ways similar to the above general provisions. However, questions arise with concretization due to the wide range of issues regulated by sanitary and epidemiological legislation.

The authors believe that the threat of mass disease or poisoning of people implies the creation of a real danger caused by the penetration of pathogenic microorganisms, endotoxins or compounds of an exogenous nature into the body, and that can cause harm to the life and health of a significant number of the population in a certain area, due to violation of sanitary and epidemiological legislation. Based on the proposed understanding, for the objective side of the crime, the material consequences are not so important as the admitted disdain for the current regulatory prescriptions. Meanwhile, as already noted in this study, there is a problem in distinguishing this criminal act from an administrative offense in accordance with parts 1 and 2 of article 6.3 of the RF CAO due to identical qualifying characteristics. In confirmation, we will formulate and analyze two model situations of violations of sanitary and epidemiological legislation.

The first model situation. An official of an organization whose activities are related to the production, storage, transportation and sale of food products allowed a person to work without a mandatory preliminary medical examination (certification). The official duties of the person included the preparation of dishes, that is, direct contact with food products was carried out. Later it was established that in violation of the provisions of Article 11, paragraph 1 of Article 17, Article 34 of the Federal Law "On the Sanitary and Epidemiological Welfare of the Population" [14], the official allowed to work a person suffering from a certain infectious disease (for example, Salmonella DNA). According to the results of a sanitary and bacteriological study carried out by the authorized federal executive body, food products were contaminated with pathogenic microorganisms. A mass infectious disease was avoided owing to the timely withdrawal from circulation of the relevant food products, on the basis of clause 1 of article 24 of the Federal Law "On the quality and safety of food products" [15].

The second model situation. During the installation work at the petrochemical enterprise, technological violations were made, accompanied by the release of pollutants into the atmospheric air of the urban settlement. The authorized federal executive body, within the framework of social and hygienic monitoring, registered an excess of the maximum permissible concentration of formaldehyde in the atmospheric air by three times, with a maximum one-time rate of $0.05 \mathrm{mg} / \mathrm{m} 3$. [16]. The verification measures to identify the cause of the incident established that the official of the enterprise responsible for compliance with sanitary 
rules and regulations did not organize constant production control over compliance with the standards for emissions of harmful (polluting) substances into the atmospheric air, and also did not take into account the qualitative and quantitative composition emissions of harmful (polluting) substances and their sources. Mass poisoning of people in the urban settlement was avoided due to a sharp change in wind speed.

In the presented model situations, there was a real threat of mass illness or poisoning of people. The officials acted inadvertently, foresaw the possibility of socially dangerous consequences in the form of a possible mass illness or poisoning of people, but without sufficient grounds for that, they arrogantly hoped not to come or to prevent these consequences. Before the introduction of amendments to part 1 of Article 236 of the RF CC, a similar criminal inaction of officials was undoubtedly qualified under Part 1 of Article 6.3 of the RF CAO "Violation of legislation in the field of ensuring sanitary and epidemiological well-being of the population, expressed in violation of existing sanitary rules and hygienic standards, failure to comply with sanitary and hygienic and anti-epidemic measures". An administrative offense, an equally bordering crime, shall be considered completed regardless of the occurrence of harmful consequences. A significant threat to protected public relations lies in the dismissive attitude of officials to the performance of their duties.

\section{CONCLUSION}

At the end of the study, we state the effectiveness of the textual content of Article 236 of the RF CC. The rapidly deteriorating epidemiological situation literally pushed the legislator to introduce certain regulatory guidelines with the expectation that such events will not recur in the future. It is possible to overcome the indicated conflict of laws in the application of criminal law or administrative law by issuing an explanatory act by the Plenum of the Supreme Court of the Russian Federation to ensure the uniform application of the law.

\section{REFERENCES}

[1] Code of Administrative Offenses of the Russian Federation of 30.12.2001 N 195-FZ (as amended on 31.07.2020), Rossiyskaya Gazeta, N 256, 31.12.2001.

[2] The Criminal Code of the Russian Federation of 13.06.1996 N 63-FZ (as amended on 31.07.2020), Collected Legislation of the Russian Federation, 17.06.1996, N 25, art. 2954.

[3] I. V. Soshnikova, V. A. Rukoleev, Difference between crimes against constitutional human and civil rights and freedoms from administrative offenses and minor acts, Ural Journal of Legal Research 5 (2019) 661-669.

[4] On amendments to the Criminal Code of the Russian Federation and Articles 31 and 151 of the Criminal Procedure Code of the Russian Federation: Federal Law of 01.04.2020 N 100-FZ, Rossiyskaya Gazeta, N 72, 03.04.2020.

[5] On the approval of the list of socially significant diseases and the list of diseases that pose a danger to others: Decree of the Government of the Russian Federation of 01.12.2004 N 715 (ed. Of 31.01.2020), Rossiyskaya Gazeta, N 271, 07.12.2004.

[6] Review of selected issues of judicial practice related to the application of legislation and measures to counter the spread in the territory of the Russian Federation of a new coronavirus infection (COVID-19) N 1 (approved by the Presidium of the Supreme Court of the Russian Federation on April 21, 2020), Official documents, N $18-19,19-25.05 .2020$.

[7] On the approval of the Rules of Conduct, binding on citizens and organizations, upon the introduction of a high alert or emergency situation: Resolution of the Government of the Russian Federation of 02.04.2020 N 417, Rossiyskaya Gazeta, N 75.

[8] Review of certain issues of judicial practice related to the application of legislation and measures to counter the spread of a new coronavirus infection (COVID-19) $\mathrm{N} 2$ in the territory of the Russian Federation (approved by the Presidium of the Supreme Court of the Russian Federation on April 30, 2020), SPS "ConsultantPlus". http://www.consultant.ru/ (date of access: 25.06.2020).

[9] On the refusal to accept for consideration the request of the Kurgan City Court of the Kurgan Region on checking the constitutionality of part one of Article

3, Article 10 of the Criminal Code of the Russian Federation and paragraph 13 of Article 397 of the Criminal Procedure Code of the Russian Federation: Determination of the Constitutional Court of the Russian Federation of 10.07.2003 N 270-O // Bulletin of the Constitutional Court of the Russian Federation, $\mathrm{N}$ 5, 2003.

[10] O. Korostylev Threat in criminal law: concept, types, meaning, Ugolovnoye Pravo 3 (2006) 37-40.

[11] E.N. Makarova, Concept, types and value of the threat as part of criminal activity, Vestnik of the St. Petersburg University of the Ministry of Internal Affairs of Russia 4 (76) (2017) 100-102. 
[12] On some issues of judicial practice in criminal cases of terrorist crimes: Resolution of the Plenum of the Supreme Court of the Russian Federation of 09.02.2012 N 1 (as amended on 03.11.2016), Bulletin of the Supreme Court of the Russian Federation, N 4, April 2012.

[13] On the application by courts of legislation on liability for violations in the field of environmental protection and natural resource use: Resolution of the Plenum of the Supreme Court of the Russian Federation of 18.10.2012 N 21 (as amended on 30.11.2017), Bulletin of the Supreme Court of the Russian Federation, N 12, December, 2012.
[14] On the sanitary and epidemiological well-being of the population: Federal Law of March 30, 1999 N 52FZ (as amended on July 26, 2019), Rossiyskaya Gazeta, N 64-65, 04/06/1999.

[15] On the quality and safety of food products: Federal Law of 02.01.2000 N 29-FZ (as amended on 01.03.2020), Rossiyskaya Gazeta, N 5, 10.01.2000.

[16] On the approval of hygienic standards GN 2.1.6.3492-17 "Maximum permissible concentrations (MPC) of pollutants in the air of urban and rural settlements": Resolution of the Chief State Sanitary Doctor of the Russian Federation of 22.12.2017 N 165 (as amended on 31.05.2018 ), SPS "ConsultantPlus". 